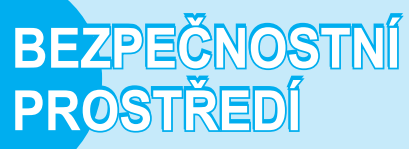

Plukovník gšt. Mgr. Ing. Libor Kutěj, Ph.D.

Sinajské bezpečnostní

souvislosti

Vojenské rozhledy, 2013, roč. 22 (54), č. 4, s. 58-70, ISSN 1210-3292

\title{
Sinai: The Contexts of Security
}

\section{Abstrakt:}

Př́spěvek se zabývá současnou bezpečnostní situací na Sinajském poloostrově. Poukazuje na vybrané aspekty utvářející tamní negativní trendy ve vývoji bezpečnostní situace a jejich vzájemnou provázanost, to vše v kontextu společenských pohybů po událostech tzv. arabského jara a di̊sledků egyptské Lotosové revoluce, která zásadním způsobem proměnila možnosti egyptských ozbrojených sil a bezpečnostních složek v tomto teritoriu. Součástí je krátký historický exkurz, stručné seznámení s problematikou egyptsko-izraelské mírové smlouvy upravující zvláštní status Sinaje jako demilitarizovaného území a zohlednění socioekonomické reality beduínského obyvatelstva mající rozhodující vliv na popisovanou situaci.

\section{Abstract:}

The article deals with contemporary security situation in the Sinai Peninsula. Attention is paid to certain aspects that form the local negative trends in security developments and their mutual interconnection, as a part of social movements after the events of the so-called Arab Spring and the consequences of the Egyptian Lotus Revolution that have a cardinal influence for both the deployments of Egyptian Army and the security sector in this territory. The opening part of this article is a brief historical excursion into the peace agreement between Egypt and Israel that arranges the special status of the Sinai as a demilitarized area and the adjustment of social-economic reality of the Bedouin population performing decisive influence for described situation.

\section{Klíčová slova:}

Egypt, Izrael, egyptsko-izraelská mírová smlouva, Sinajský poloostrov, demilitarizace Sinaje, beduíni, mnohonárodní síly a pozorovatelé, terorismus, saláfismus, militantní islamistické skupiny.

\section{Key words:}

Egypt, Israel, Egypt-Israel Peace Treaty, the Sinai peninsula, demilitarization of Sinai, Bedouins, multinational force and observers, terrorism, Salafism, militant Islamist groups. 
Oblast Sinajského poloostrova si naprostá většina Středoevropanů spojuje s rekreačními pobyty v letoviscích na břehu Rudého moře, př́ípadně s několika málo biblickými místy nacházejícími se v této rozlehlé oblasti. Dokonce i v období Mubarakova Egypta byly autobusové kolony přepravující turisty na fakultativní výlety mimo hlavní letoviska a obydlené lokality eskortovány turistickou policií. Turisté však tehdy byli ohrožováni jen zřídka a primárně se jednalo o kriminální činnost za účelem ekonomického profitu bez zjevných širších politických konsekvencí.

Po začátku společenských pohybů v nejlidnatější arabské zemi se však počala dramaticky proměňovat též vnitřní bezpečnostní situace na Sinaji a její neutěšenost se projevovala i v mezinárodním kontextu. Přestože rozhodující zprávy o egyptském vnitropolitickém vývoji se vztahují k dění v tzv. centrálním Egyptě s velkými centry osídlení, jakými jsou zejména Káhira a Alexandrie, je o Sinaji v uplynulých několika měsících stále více mediálně slyšet. Zprávy z poloostrova reflektují aktuální bezpečnostní situaci s bezprostředním vlivem na turistický ruch v oblasti a v jejich důsledku ministerstva zahraničí evropských a dalších západních zemí opakovaně varují své občany před cestami mimo hlavní letoviska.

Předkládaný prríspěvek má za cíl poukázat na komplexnost bezpečnostních problémů Sinajského poloostrova, přičemž dopady na zisky z cestovního ruchu jsou ve světle dalších regionálních souvislostí pouhou marginalitou.

\section{Vojensko-strategický rozměr a novodobý historický vývoj}

Trojúhelníková oblast Sinajského poloostrova zaujímá plochu 61100 km², což pro srovnání představuje 77,5\% rozlohy ČR. Jeho povrch je převážně hornatý a pouštní, v jižní oblasti s pohořím Rudé hory a nížinou podél Rudého moře. Nejvyšším bodem poloostrova je hora Jabal Katrinah (hora Sv. Kateřiny) s nadmořskou výškou 2642 m. V oblasti jižní Sinaje se též nachází biblická hora Sinaj s výškou 2285 m, kde podle Bible (Exodus 19-20) daroval Hospodin Mojžíšovi Desatero prrikázání. Přilehlé Rudé moře je pojmenováno podle červené barvy okolního pohoří. Jižní strana poloostrova se ostře svažuje do úzkého pobřežního šelfu Rudého moře a Akabského zálivu. Průměrná nadmořská výška jižního okraje Sinaje dosahuje 1000 m a směrem k severu se snižuje. Severní třetinu Sinaje pak tvoří plochá, písečná pouštní pobřežní pláň táhnoucí se od Suezského průplavu na západě k pásmu Gazy a izraelské hranici na východě. Egyptská vláda dělí oblast Sinajského poloostrova administrativně na dvě provincie - Severní Sinaj s administrativním centrem El-Aríš a jižní Sinaj s administrativním centrem At-Tur. [1]

Název Sinaj nemá jednoznačný původ, ale zpravidla se odvozuje od semitského slova „,sen“, což v překladu znamená ,zub“ a má odkazovat na četné horské vrcholy v oblasti, nebo ze slova „hřích“ a vážící se k uctívání bohyně Měsíce v prehistorickém období. [2]

Přestože oblast byla od pradávna důležitou křižovatku cest mezi Severem a Jihem, mezi Východem a Západem, a tvořila nárazníkové pásmo egyptské říše mezi ní a Levantou, její dnešní strategicko-vojenský rozměr nabyl na významu v době válečných konfliktů a ozbrojených střetů mezi Egyptem a Izraelem po roce 1948.

Sinajské tažení v roce 1956 bylo tím prvním. Započalo v pondělí 29. 10. 1956 za setmění, kdy podle předchozí dohody mezi předsedou izraelské vlády Ben Gurionem, 
francouzským premiérem Molletem a britským ministrem zahraničí Lloydem izraelské jednotky obsadily oblast okolo průsmyku Mitla, dobyly město Rafáh nacházející se v blízkosti pásma Gazy, a na jihu pronikly od Eilatu na východním pobřeží Sinaje až k Šarm aš-Šajchu na jižním výběžku Sinajského poloostrova. Po 5. 11. 1956 byla celá Sinaj, až na uznávané šestnáctikilometrové pásmo východně od Suezského průplavu, v izraelských rukou. Izraelským motivem pro tuto vojenskou invazi byla snaha o zajištění volné plavby pro izraelská plavidla v Akabském zálivu, likvidace fedajínů, [3] a následné zamezení obnovení jejich základen. Na základě mezinárodního tlaku na Izrael, ale též na Velkou Británii a Francii ze strany USA a Sovětského svazu, bylo 7. 3. 1957 rozhodnuto o stažení izraelských sil ze sinajské oblasti, přičemž východní Sinaj a pásmo Gazy převzaly jednotky OSN. [4]

Druhým konfliktem, který měl pro teritorium Sinaje rozhodující politický a vojenskostrategický význam a dodnes ovlivňuje bezpečnostní uspořádání na poloostrově, byla tzv. šestidenní válka, která začala v ranních hodinách 5. 6. 1967 jako preemptivní úder izraelských ozbrojených sil proti početným arabským - egyptským, syrským a později též jordánským vojskům soustředěným na hranicích s Izraelem. V průběhu této války byl celý Sinajský poloostrov dobyt a obsazen vítěznými izraelskými jednotkami.

V důsledku šestidenní války se strategická situace Izraele zásadním zpo̊sobem proměnila a země získala, poprvé od svého vzniku, výhodu obrany v hloubce. Sinajská poušt' sloužila jako nárazníkové pásmo a Izrael nyní kontroloval území, která byla dříve protivníky využívána jako nástupní prostor k útokům na něj. Izrael věřil, že tato realita, bude-li správně využita, může otevř́it cestu k mírovým jednáním. Obecně však lze konstatovat, že izraelské vítězství v této válce bylo natolik ohromující a neočekávané, že izraelské vrchní velení získalo sklon k tomu, připisovat svému vojenskému umění i úspěchy, které byly v řadě případů spíše důsledkem nedbalosti, nedostatečné součinnosti a špatného velení arabských vojsk. Tato skutečnost se negativně projevila o šest let později, kdy se Sinaj opět stala dějištěm prudkých bojů. Jako nesporné pozitivum s klíčovým významem, a to zejména po překročení Suezského kanálu egyptskými vojsky v roce 1973, se však ukázalo využití obsazeného poloostrova jako nárazníkového pásma.

Dalším významným aspektem obsazení Sinaje bylo i dobytí nejjižnějšího výběžku poloostrova ovládajícího strategicky významnou Tiranskou úžinu představující vstup do Akabského zálivu. Na dobytém území se rovněž nacházela ropná pole při březích Suezského průplavu, která byla schopna pokrýt velkou část izraelské spotřeby této suroviny. Součástí vytvoření nárazníkového pásma na Sinaji bylo též vybudování elektronických systémů včasné výstrahy, díky kterým se možná reakční doba izraelských ozbrojených sil před eventuálním úderem egyptského letectva prodloužila čtyřnásobně, tedy až na 16 minut. [5]

Sinaj, nejrozlehlejší dobytá oblast, byla velice řídce osídlena a větší města byla jen na východní straně průplavové zóny. Jejich obyvatelstvo uprchlo při bojích o průplav na jeho západní stranu. Mimoto existoval jistý počet menších osad jako El-Aríš nebo At-Tur, zastř̌ešující podnik na zpracování manganové rudy v Um Bogma, a řada větších vojenských táborů. Na východním pobřeží žádná větší sídla nebyla. Většinu obyvatelstva tvořili beduíni. Sinaj byla k Egyptu přičleněna až v roce 1906 a její beduínské obyvatelstvo se nikdy necítilo jako skuteční Egypt’ané. Izraelci uvalili na celou oblast vojenskou správu, přičemž samotní izraelští občané ji z počátku mohli navštívit pouze na základě vojenského povolení. S obyvatelstvem Sinaje nebyly za celé roky izraelské 
okupace žádné problémy. Na rozdíl od jiných území obsazených v roce 1967 se pouštní krajina na východním pobřeží Sinaje nehodila pro zemědělství, a proto zde vzniklo několik městských center žijících z turistiky. Oblast se záhy stala předmětem rostoucího turistického zájmu z Izraele, ze kterého měli největší zisky místní beduíni. Roku 1969 zahájil Izrael výstavbu asfaltové silnice spojující Eilat s Šarm aš-Šajchem, po které proudilo velké množství výletníků do nitra vysokohorského jihu Sinaje. [4]

Dne 19. 7. 1967 izraelská vláda jednomyslně schválila vrácení celé Sinaje Egyptu výměnou za uzavření mírové smlouvy, demilitarizaci poloostrova a zvláštní statut Šarm aš-Šajchu. Tyto snahy však byly zablokovány sovětskou aktivitou, která vyústila v summit vedoucích představitelů arabských států v súdánském Chartúmu s výslednými třemi ,ne“ - nejednat s Izraelem, neuznat Izrael a neuzavřít s Izraelem mírovou smlouvu. [5]

Sinaj se ani pod izraelskou vojenskou správou nestala poklidným místem a od července 1967 až do vypuknutí další války v říjnu 1973 byla dějištěm tzv. opotřebovací války. Přestřelky a incidenty v pásmu kolem kanálu působily lidské i materiální ztráty na obou stranách linie.

Egyptský prezident Gamál Abd An-Násir si z porážky v šestidenní válce vzal ponaučení a vypracoval dlouhodobou strategii na znovudobytí Sinaje a dalších území ztracených v roce 1967, založenou na kombinaci politických a vojenských opatření, u kterých jedinou možnou alternativou byla ofenziva provedená v co největším měřítku. Konkrétní náznaky egyptských příprav na válku nezůstaly izraelské rozvědce utajeny, ta je však nesprávně vyhodnotila a $\mathrm{v}$ atmosféře sebeuspokojení $\mathrm{z}$ vítězství v šestidenní válce byly i nejmarkantnější zpravodajské indicie ignorovány nebo dezinterpretovány. Nálad v Izraeli využili i samotní Egyptané a spustili klasickou dezinformační kampaň založenou na pečlivé analýze názorů a představ vládnoucích v Izraeli a čas od času veřejně vyjadřovaných jednotlivými vojenskými veliteli. Pro účel dezinformační kampaně byl ve struktuře egyptského velení vytvořen speciální štáb, [5] který dohlížel na průběh klamné operace a řídil ji tak, aby jí uvěřili nejen v Tel Avivu, ale též ve Washingtonu i jinde. I v důsledku tohoto zastihl útok egyptských a syrských vojsk 6. 10. 1973 Izraelce zcela nepřipravené a v prvních válečných dnech bojovali čistě defenzivně. Teprve 14. 10. 1973 se Izraelcům podařilo převzít iniciativu a zmařili urputný pokus egyptských sil o průnik do nitra Sinaje. O dva dny později se jednotce pod velením generála Ariela Šarona podařil průnik severně od místa, kde Egypt’ané překročili Suezský průplav, a v následujících dnech Izraelci ovládli celé území na západním břehu průplavu, čímž egyptskou invazní armádu, představovanou 3. polní armádou nacházející se na východní straně průplavu, odřízli od jejího zázemí. Všechny zbraně utichly, až když izraelské jednotky 26. 10. 1973 úplně obklíčily egyptskou 3. armádu. Bizarní průběh války, označované na izraelské straně jako tzv. jomkippurská válka podle židovského svátku, ve který začala, a na egyptské straně jako říjnová válka, umožňoval oběma stranám označit se za vítěze a každá si mohla připisovat velké úspěchy v určitých fázích konfliktu. Vojenská situace po ukončení bojů však nebyla výhodná pro žádnou stranu, a tak ihned začala vyjednávání o přerozdělení vojsk, která byla poprvé od uzavření příměří v roce 1949 přímá a velmi plodná. Na základě společné dohody opustili poslední izraelští vojáci západní břeh Suezského kanálu 4. 3. 1974, dodatečně se stáhli i z celé oblasti průplavu a dali tak Egyptu možnost opět jej otevřít pro mezinárodní plavbu. [4] 


\section{Mírová smlouva a demilitarizace Sinaje}

V roce 1979 byla mezi Egyptem a Izraelem uzavřena mírová smlouva. Po celé třicetileté období vlády prezidenta Mubaraka v Egyptě tvořila pevný pilíř vzájemných vztahů, které byly nejlepší v celé éře od vzniku novodobého židovského státu. Smlouva byla uzavřena z vysoce pragmatických důvodů a odolala i řadě politických kroků, které ostatní arabské státy podnikly vůči Egyptu jako první arabské zemi, která uznala právo Izraele na vlastní existenci.

Po podpisu samotné smlouvy dne 26. 3. 1979 byla v letech 1979 až 1983 podepsána série dílčích normalizačních dohod mezi oběma signatáři v oblastech obchodu, letectví, kultury, zemědělské spolupráce, celní spolupráce, cestovního ruchu a dalších. [6]

Pro vnímání současných hrozeb, jak budou dále popsány, a možností, jak jim čelit, je rozhodující článek 2 části III smlouvy, ve kterém se Egypt a Izrael zavazují zajistit, že akty nebo hrozby válečného stavu, nepřátelství nebo násilí nebudou pocházet z jejich území a od jakýchkoli sil nacházejících se pod jejich kontrolou či umístěných na jejich teritoriu. [7] Tímto se oba státy zavázaly zabránit využívání svého území k činnosti teroristických skupin proti druhému signatáři. V kontextu současné situace na Sinaji a vzhledem k aktivitám dobře organizovaných hnutí, jakými jsou Hamás, Islámský džihád a al-Ká'ida, to utváří situaci, kdy je především Egypt svrchovaně odpovědný a povinen jednat tak, aby nedocházelo k ohrožování Izraele teroristickými útoky vedenými z oblasti Sinajského poloostrova. [6]

V článku II. Př́lohy I. smlouvy, kterou je Protokol o stažení Izraele a bezpečnostní dohody, jsou definovány teritoriální zóny, na které je Sinaj rozdělen pro potřebu dosažení maximální míry bezpečnosti obou smluvních stran po stažení izraelských sil. Celý poloostrov je tímto rozdělen do tří zón - A, B a C na egyptské straně, a D na izraelské straně hranice, přičemž protokol v zájmu implementace smlouvy explicitně vymezuje množství a typy vojenské výzbroje a vojenského personálu, který může být v jednotlivých zónách dislokován. Pro naši potřebu je potřebné reflektovat především zóny vymezené na egyptské straně hranice.

V zóně A, jejíž západní linii tvoří Suezský průplav, může egyptská armáda udržovat vojenské jednotky o síle mechanizované pěší divize, vojenská zařízení a polní opevnění, za předpokladu, že hlavní elementy této divize budou tvořit 3 mechanizované pěší brigády, 1 obrněná brigáda, 7 praporů polního dělostřelectva, 7 praporů protiletadlového dělostřelectva, do 230 tanků, do 480 obrněných vozidel všech typů a celkového počtu 22000 vojenského personálu. [7]

V zóně B smí Egypt udržovat 4 prapory pohraničních jednotek vyzbrojených lehkými zbraněmi a kolovými vozidly, přičemž tyto jednotky, čítající maximálně 4000 mužů, budou sloužit k podpoře činnosti civilní policie při plnění bezpečnostních úkolů na teritoriu zóny. [7]

V zóně C, jejíž východní linii tvoří mezinárodní hranice s Izraelem, může být přítomna pouze egyptská civilní policie vybavená lehkými zbraněmi a jednotky OSN. Na izraelské straně, tedy v zóně D, je Izrael oprávněn udržovat jednotky do síly 4 pěchotních praporů (s nejvýše 180 obrněnými vozidly), včetně jejich vojenských zařízení a polních opevnění, avšak s výjimkou tanků, dělostřelectva a protiletadlových systémů, mimo střel země-vzduch. Protokol též omezuje vojenský letecký provoz nad jednotlivými zónami. [7] 
Po vítězství exponentů Muslimského bratrstva v egyptských parlamentních volbách po svržení Mubarakova režimu byla další budoucnost egyptsko-izraelské mírové smlouvy velmi diskutována. Je však pravdou, že tyto diskuze nebyly vedeny politickými představiteli, a pokud, tak nikoli na té úrovni a na takových fórech, aby jejich prohlášení musela být brána za stěžejní pro predikci skutečných záměrů především egyptských politiků. Pokud docházelo k širokým disputacím o budoucnosti mírové smlouvy, pak zejména v akademických kruzích, a to nejvíce izraelských a amerických a na těch pracovištích, které se ve své činnosti orientují výhradně či především na blízkovýchodní mezinárodněpolitickou a bezpečnostní problematiku. Vlivem egyptských vnitropolitických pohybů a šírí tamní názorové platformy byly komentovány varianty od úplného vypovězení smlouvy Egyptem až po vypovězení doprovodných dohod upravujících jiné oblasti potenciální egyptsko-izraelské spolupráce. Zpravidla však byly akceptovány názory, podle kterých by vypovězení smlouvy znamenalo nejistotu především pro Egypt, který jednak není s to reálně se vojensky poměřovat s Izraelem, a jednak by to přineslo nejistotu pro nově vládnoucí garnituru spočívající v možném izraelském preventivním vojenském úderu, jakkoli omezenému na vybrané egyptské teritorium (především Sinaj), nebo v ekonomických dopadech, zejména omezením či pozastavením americké vojenské pomoci Egyptu ve výši cca 1,5 miliardy dolarů ročně.

V rámci takových diskuzí izraelský expert na mezinárodní právo a bývalý velvyslanec v Kanadě Alan Baker správně poukazuje na skutečnost, že ukončení válečného stavu a nastolení míru mezi Egyptem a Izraelem v souladu s částí I. smlouvy vytvořilo nový právní a politický rámec přesahující pouhou smluvní terminologii a vypovězení smlouvy by tak vracelo válečný stav mezi oběma zeměmi, [6] což je s ohledem na realitu v regionu v př́krém rozporu s nezbytným politickým pragmatismem egyptských představitelů, bez ohledu na jejich agresivní rétoriku.

Největším paradoxem smlouvy je, že ačkoli po více než třicet let umožnila oběma signatářským zemím užívat její nástroje - demilitarizaci a kontrolní mechanismy k zachování míru a stability na Sinaji, je to právě absence egyptských vojenských jednotek, která na tak rozsáhlém území umožnila rozvoj pašeráctví a teroristických aktivit. Charakter smlouvy byl standardní pro ujednání mezi dvěma státními subjekty, mezi nimiž probíhal válečný konflikt, avšak nepředjímal situaci, kdy jeden ze signatářů se stane státem, který nemá plnou kontrolu nad určitou částí vlastního území, která se dostane pod kontrolu nestátních aktérů s jejich nejrůznějšími parciálními zájmy a schopnostmi jejich prosazování.

\section{Monitorovací mise}

K implementaci bezpečnostních opatření v příloze I. egyptsko-izraelské mírové smlouvy bylo v roce 1981 oběma stranami formou Protokolu ke smlouvě dohodnuto, že bude vytvořena nezávislá mezinárodní organizace monitorující dodržování smluvních ujednání na Sinaji (MFO - Multinational Force and Observers). K vytvoření této formy kontrolního mechanismu bylo signatářskými stranami přistoupeno poté, co se nepodařilo získat souhlas Rady bezpečnosti OSN s rozmístěním sil OSN v oblasti poloostrova. Posláním MFO je dohlížet na dodržování bezpečnostních ustanovení smlouvy a vyvinout maximální úsilí k zabránění jejich porušování. K aplikaci uvedeného je MFO 
oprávněno zřizovat kontrolní stanoviště, provádět průzkumná patrolování a zřizovat pozorovací stanoviště podél mezinárodní hranice, linie B a uvnitř zóny $\mathrm{C}$. MFO dále provádí pravidelná ověřování dodržování ustanovení př́ilohy I. smlouvy a pokud není smluvními stranami dohodnuto jinak, toto realizovat dvakrát v měsíci. Mimořádně lze, na základě žádosti jedné ze smluvních stran, provést ověření do 48 hodin. MFO je současně odpovědné za zajištění svobodné plavby Tiranskou úžinou. V souladu s podmínkami dohodnutými smluvními stranami 1. 9. 2005 dále MFO provádí ověřování nasazení pohraniční stráže podél hranice mezi Egyptem a Gazou v severovýchodní oblasti zóny $\mathrm{C}$, kdy se organizace zaměřuje na verifikaci povoleného počtu osob, jejich výzbroje a infrastruktury. [8]

Ústředí MFO bylo zřízeno na neutrálním území v italském hlavním městě Římě. $\mathrm{V}$ čele je generální ředitel, který je civilním diplomatem amerického ministerstva zahraničí. Tento je v signatářských zemích zastupován představiteli MFO (tzv. director general's representatives) v Káhiře a Tel Avivu, kteří jsou taktéž civilními úředníky. V čele vojenského kontingentu stojí dvouhvězdičkový generál, náčelníkem jeho štábu je americký plukovník. Samotný vojenský kontingent je tvořen 1660 příslušníky ozbrojených sil 13 zemí, mezi nimiž je taktéž ČR, která od 17. 11. 2009 obsazuje v organizaci tři štábní pozice v hodnostech podplukovník, major a kapitán. Obsazení funkcí strukturovaných pro tyto vojenské hodnosti představuje velký úspěch naší diplomacie, která zastoupení ČR v MFO vyjednávala. Je potřebné zohlednit, že ČR nemá žádný jiný vojenský podíl v organizaci a nepatří ani mezi její finanční dárce participující na provozu organizace (Egypt se na provozu organizace podílí z 31,6\%, stejně jako Izrael 31,6\% a USA 31,6\%; zbytek nákladů je rozdělen mezi dalších 9 zemí, z nichž žádná není státem blízkovýchodního regionu). [9]

Veškerý personál MFO dislokovaný na Sinaji je umístěn na dvou základnách. Severní základna, tzv. North Camp se nachází v lokalitě El-Gorah cca 20 km jižně od pobřeží Středozemního moře. Je sídlem velitele sil MFO a jeho štábu a rozhodujícího množství vojenských kontingentů působících v organizaci. Základna má velikost přibližně 2,7 km². Menší základna, označovaná jako South Camp, je dislokovaná v jižním cípu poloostrova v blízkosti města Šarm aš-Šajch. Ta je svou velikostí a vybavením uzpůsobená potřebám vojenské jednotky o velikosti zesíleného praporu. [8]

V případě, že pozorovatelé MFO zjistí porušení podmínek mírové smlouvy, nedisponují mandátem k tomu, aby takovému porušení zabránili. Jejich úkolem je cestou velitele sil MFO informovat o vzniklém incidentu generálního ředitele organizace v Římě, který pak cestou svých představitelů v Káhiře a Tel Avivu informuje smluvní strany. Ty spolu vzájemně komunikují prostřednictvím určených představitelů styčných orgánů ozbrojených sil Egypta (Chief of the Egyptian Liaison Agency with International Organizations) a Izraele (Head of the Israel Defense Force Strategic Division), kteří se pravidelně, a dále podle aktuální potřeby, scházejí k projednání nejen vzniklých incidentů, ale všech okolností vážících se k implementaci podmínek protokolu. Egyptsko-izraelské vztahy na této úrovni lze označit za velmi korektní a jejich kvalita nebyla negativně narušena ani po lednu 2011 při událostech tzv. arabského jara v Egyptě, a představitelé ozbrojených sil se v tomto směru vždy chovali vysoce pragmaticky. [9]

Přes na první pohled poklidný charakter mise, kterou MFO na Sinaji plní, se ani její příslušníci v minulosti nevyhnuli konfliktním situacím, při kterých byla ohrožena jejich fyzická bezpečnost. Ačkoli již kupř. v roce 2005 bylo vozidlo MFO zasaženo 
výbušninou umístěnou na silnici, zásadní nárůst ohrožení příslušníků mise lze zaznamenat po událostech egyptské revoluce započaté 25. 1. 2011. V březnu 2012 skupina ozbrojených beduínů na osm dnů obklíčila základnu North Camp a požadovala po centrální egyptské vládě propuštění svých soukmenovců uvězněných za bombové útoky v Tabě a Šarm aš-Šajchu v letech 2004 a 2005. O měsíc později další skupina beduínů zadržela vozidlo MFO pohybující se mezi dvěma kontrolními stanovišti. V září 2012 desítky beduínských militantů s využitím terénních a užitkových vozidel překonaly plot základny North Camp, podpálily vozidla mise a pozorovací stanoviště u vjezdu na základnu, zničily elektronická a komunikační zařízení a zmocnily se munice. [10, 11]

\section{Obyvatelstvo a sociálně-ekonomická realita}

Majoritní obyvatelstvo Sinajského poloostrova představují beduínské kmeny, původní kočovníci, kterým bylo umožněno ponechat si vlastní kulturu a zvyky, a kteří dodnes nepřijali egyptský dialekt arabštiny. Území obývané beduíny nikdy nemělo vlastní vládu, a tak nikdy nemělo rozhodující vliv na utváření dějin v oblasti. Místní beduíni, kterých na Sinaji žije okolo 300 000, tvoří $70 \%$ celkového počtu osídlení poloostrova, $10 \%$ jsou Palestinci na severu, prristěhovalci imigrující přes Suezský průplav (10\%) a potomci Bosňáků, Turků a jiných osadníků z doby osmanského impéria, kteří jsou většinou usídleni v severním městě El-Aríš. Všechna tato etnika byla spíše dějinnými diváky než tvůrci širších regionálních událostí a svou energii vybíjela především v mezikmenových válkách než ve větších konfliktech. Sinaj však nyní prochází dramatickým vývojem a po pádu Mubarakova režimu se beduíni ocitli v situaci, ve které ovlivňují nejen egyptsko-izraelské vztahy, ale i širší regionální bezpečnostní realitu. Sinajští beduíni se vždy považovali za dobré muslimy, ale současně si udržovali odstup od fundamentalistických forem islámu arabského světa. Současný nárůst islámského radikalismu mezi beduíny je novým, dosud bezprecedentním trendem a odporuje jejich tradičnímu pojetí víry. Náboženství se stává významným prvkem utváření světonázoru beduínů, hojně podporovaného výstavbou stovek mešit financovaných centrální egyptskou vládou. Tradiční súfismus [12] byl od počátku 80. let minulého století vytlačován saláfismem, [13] který si s sebou přinášeli mladí beduíni ze svých studií na univerzitách v nilské deltě (zejména v Zaqaziq, známé jako pevnost islámských radikálů) a domorodci vracející se z dlouholetých pracovních pobytů v Saúdské Arábii. Vlivem těchto náboženských trendů mladá generace beduínských mužů začala měnit styl svého oblékání, nechávala si narůst dlouhé vousy a nahradila tradiční ženské pokrývky hlavy přísnějším nikábem. Na rozdíl od tradičních beduínských zvyků se začaly množit sňatky mezi příslušníky soupeřících kmenů. Ve stále větší míře docházelo ze strany této „nové beduínské generace“ $\mathrm{k}$ bojkotu jednání s egyptskými úředníky a započalo zpochybňování tradiční nadřazenosti kmenových šejchů. Současně s tím došlo k erupci saláfistických kázání a islámského vzdělávání. Na počátku 90. let 20. století se saláfisté pustili do divoké konfrontace s tradičním súfijským uspořádáním na Sinaji. Saláfisté označují súfijskou náboženskou praxi na neislámskou, zatímco súfíjci označují saláfisty za Západem zmanipulované wahabisty. [14] Tato konfrontace vedla k rozkolu uvnitř kmenových a rodinných jednotek a podkopala sociální strukturu mnoha beduínských komunit. Dnes lze po celém poloostrově nalézt tábory saláfistických beduínů, kteří opustili své kmeny v zájmu uspořádání života podle nové islámské nauky. [15] 
Dalším klíčovým faktorem pro vnímání sinajské reality je tamní ekonomická situace. Oblast patří mezi nejchudší místa planety. Od stažení izraelských vojsk jsou beduíni centrální káhirskou vládou v praxi považováni za druhořadé obyvatelstvo a takto je s ním též zacházeno. Beduíni nemají žádný příjem z cestovního ruchu (ačkoli si nárokují pozemky, na kterých jsou turistické komplexy postaveny), z těžby nerostných surovin na poloostrově, ani z přepravy plynu do Izraele. V pracovně lukrativních pozicích jsou téměř výlučně zaměstnáváni Egypt’ané z nilské oblasti. Starší generace beduínů vzpomíná na období izraelské okupace poloostrova, kdy se beduínům dostalo participace na zabezpečení chodu izraelských základen. I z těchto důvodů Egypt’ané nazývají beduíny „sinajští Židé“, [16] což jen dokumentuje bezproblémovost vztahů mezi izraelskými okupanty a domorodým obyvatelstvem, ale současně též negativní vztah většinových Egypt’anů k beduínům.

Celkový nezájem centrální vlády a neutěšená ekonomická situace vytváří vhodné prostředí pro nelegální aktivity, především pašeráctví drog, zbraní, utečenců (zejména ze Súdánu a Eritreje) a východoevropských prostitutek, a nově se začíná ,podnikat“ s lidskými orgány, jak dokázaly odkryté hroby s lidskými ostatky v centrální Sinaji. Uvedené převaděčství je velmi výnosným druhem beduínského podnikání, když za převedení jednoho ilegálního imigranta na izraelské území si beduíni říkají o 500 až 3000 amerických dolarů. Důkazem zájmu o tyto jejich služby je asi 50000 nelegálních imigrantů z afrických zemí v Izraeli. [15] Ústřední vláda nemá žádný zájem v oblasti investovat a při současné egyptské makroekonomické situaci ani není předpoklad, že by se v dohledné budoucnosti v tomto mohlo cokoli změnit.

Pašeráctví je v těchto pohraničních oblastech tradiční činností a pro beduíny představuje významný zdroj obživy. Beduíni se podílejí na pašování mezi Egyptem a pásmem Gazy, k čemuž již od 90. let minulého století masově využívají tunelů spojujících obě entity. Prudký rozmach „tunelové ekonomiky“ nastal po stažení Izraele z pásma Gazy $\mathrm{v}$ roce 2005 a beduíni v souvislosti s těmito aktivitami začali rychle bohatnout a stávat se dobře vyzbrojenou milicí. [16]

\section{Teroristické sítě a protiopatření}

Některé části Sinaje se mění v rozširřenou palestinskou arénu a určité skupiny vytvářjí úzké vojenské, politické, ideologické a ekonomické vazby se sousedním pásmem Gazy. V důsledku egyptského váhání s prosazením silového řešení kontroly nad Sinají začal palestinský Hamás operující z pásma Gazy považovat přilehlý prostor severovýchodní Sinaje za sféru svého vlivu. S využitím potenciálu místního obyvatelstva tak pro své aktivity získal nové manévrovací možnosti. V posledním období roste počet teroristických uskupení, která rozšíríila svou přítomnost a sítě na Sinajském poloostrově. Tyto sítě, některé tajné, jiné naopak s významným veřejným profilem, jsou tvořeny starými pašeráckými gangy částečně se nově orientujícími na terorismus, nově vzniklými beduínskými frakcemi pod vlivem saláfistických džihádistických doktrín a přidružených palestinských organizací v Gaze, včetně Hamásu, Islámského džihádu, Výboru lidového odporu a kmenové Dughmušovy islámské armády. V roce 2010 odhalily egyptské úřady skupinu příslušníků libanonského šíitského hnutí Hizballáh působící na Sinaji. Několik členů této organizace bylo zatčeno a odsouzeno k více než 15letému vězení. Egyptští 
představitelé vždy důsledně popírali působení al-Ká’idy na Sinaji, nicméně v srpnu 2011 byla zachycena prohlášení o zřízení „Emirátu Sinajský poloostrov“. Prohlášení bylo distribuováno v okolí města El-Aríš, opakovalo dlouhodobé stížnosti beduínů na chování egyptských bezpečnostních sil a vyzývalo k boji proti Židům. Za prohlášení zřejmě nese odpovědnost jedna ze saláfistických skupin, která chtěla poukázat na své možnosti a údajně vybudované kontakty do zahraničí. Toto prohlášení následovaly výzvy vůdců etablovaných teroristických organizací, které podněcovalo nejen obecně k boji proti Židům, ale též k provádění konkrétních sabotážních útoků na plynovod do Izraele. [15]

Schopnosti skupin militantního islámu v oblasti byly ještě umocněny př́livem zbraní z Libye, včetně protitankových granátů, protiletadlových střel či high-tech zbraní. Jasnějších kontur nabyla přítomnost saláfistických militantů v průběhu roku 2012, kdy se na Sinaji oficiálně etablovala Madžlis Šúra al-Mudžáhidín, která aktivně spolupracuje s radikálními saláfisty z pásma Gazy a někteří bezpečnostní experti poukazují i na její předpokládané vazby na al-Ká'idu. Organizaci se ve zmíněném období podařilo několikrát úspěšně zaútočit na přeshraniční izraelské cíle, čímž si vydobyla vysoké uznání v džihádistické komunitě. Je nepochybné, že působení Madžlis Šúrá al-Mudžáhidín a jiných výše popsaných uskupení není na Sinaji ojedinělým fenoménem, přičemž jejich počet a schopnosti lze jen obtížně odhadovat. [17]

Policejní složky se z oblasti Sinajského poloostrova stáhly již během revoluce a v oblasti zavládlo bezprecedentní bezpečnostní vakuum, které přetrvává i poté, co se část policejních sil vrátila. Jedním z aspektů ovlivňujících nízkou angažovanost bezpečnostních složek jsou trvající útoky beduínů na představitele bezpečnosti, které mají často charakter osobní msty. Tento předpoklad potvrzuje i incident z května 2013, kdy beduíni, pravděpodobně z vlivného pohraničního kmene Sawarka, unesli sedm příslušníků egyptských bezpečnostních složek a za jejich uvolnění požadovali propuštění politických vězňů pocházejících ze Sinaje a uvězněných ještě v době Mubarakovy vlády. Rukojmí byli nakonec za nejasných okolností propuštěni. [17]

Do nedávné doby bylo bezpečnostními záležitostmi ve vztahu k beduínům pověřeno Všeobecné zpravodajství (Gihaz al-Mukhabarat al-Amma), avšak po revoluci byla tato kompetence svěřena vojenskému zpravodajství (Mukhabarat el-Kharbeya). [15]

Velení egyptských ozbrojených sil zareagovalo na stoupající počet teroristických útoků zesílenou vojenskou přítomnosti (navýšení jednotek bylo odsouhlaseno izraelskou stranou) a rozsáhlou protiteroristickou kampaní. Velení armády dokonce zvažovalo o vyhlášení výjimečného stavu nad oblastí severní a jižní Sinaje. Po loňském krvavém incidentu v oblasti Rafáhu v srpnu 2012, při kterém bylo zabito 16 př́slušníků pohraniční stráže, schválil Mursího kabinet vojenskou operaci „Orel“. [17] Ta byla realizována šesti prapory 2. armády v severovýchodní části Sinaje a podél pobřežní pozemní komunikace, avšak za několik měsíců bylo evidentní, že operace nevedla k odzbrojení beduínských milicí nebo omezení jejich mobility a k úspěchu armádních jednotek v opevněných beduínských postaveních v oblastech Jabal Halal a Wadi Arm, ale jejím výsledkem bylo pouhé zachování přítomnosti ozbrojených sil na kontrolních stanovištích a zátarasech v sinajských městech. [15]

Dlouhodobě omezenou angažovanost egyptské armády nejlépe dokumentuje fakt, že jak naznačeno výše, může mít v zóně A umístěno 22000 vojáků. Ve skutečnosti přítomnost egyptských jednotek nikdy nepřekročila 70-80\% tohoto limitu. Egyptské 
velení též nikdy nevytvořilo velitelství pro sinajskou oblast a všechny čtyři rotující brigády jsou po celou dobu působení na Sinaji pod př́mým velením divizního velitelství umístěného západně od průplavu a navíc každá brigáda patří k jiné prvosledové divizi 2. armády nebo 3. armády. Během revoluce pak byly tyto jednotky mnohdy staženy a již se do svých původních posádek nevrátily. Pokud Izrael svým souhlasem vytvoří podmínky pro prrísun egyptských jednotek do zón B a C v centrální a východní Sinaji, tak egyptské velení tuto možnost zohlední převelením jednotek, které se již nacházejí v zóně A, namísto toho, aby posily pocházely od sil rozmístěných na západním břehu kanálu. Z tohoto by se dalo usuzovat, že egyptské velení považuje roli armády na Sinaji jako čistě defenzivní a spíše se chce držet od „,beduínských problémů“ co nejdále. $\mathrm{Na}$ samotné hranici s Izraelem jsou umístěny egyptské policejní síly na 300 pozorovatelských stanovištích, přičemž tyto izolované pozice jsou obsazovány jedním policistou, nemají ani elektřinu či tekoucí vodu a nezřídka musely být logisticky podporovány izraelskými ozbrojenými silami. [9, 15]

\section{Závěr}

Předkládaný příspěvek nemá ambici komplexního popisu politické, socioekonomické, vojenské a bezpečnostní situace na egyptském Sinajském poloostrově. Snahou bylo poukázat na rozhodující aspekty tamní složité reality, která je sice v mnohém odrazem událostí uplynulých desetiletí, avšak v klíčových momentech vychází z vývoje posledních dvou let po tzv. arabském jaru vedoucímu v Egyptě ke svržení prezidenta Mubaraka a svobodným volbám, navzdory kterým se Egypt do dnešních dnů utápí v nekončícím chaosu ve všech oblastech každodenního života.

Sinaj, ač integrální součást Egyptské arabské republiky, je samotným děním v jejî centrální části ovlivňována jen minimálně a žije si svým vlastním rytmem, který je však urychlován novými fenomény v životě tamního obyvatelstva - narůstajícím vlivem saláfistického pojetí islámu a náboženskou radikalizací části původních beduínských komunit, jejich podílem na nezákonných, leč o to výnosnějších ekonomických aktivitách, narušováním tradiční kmenové hierarchie a hodnotového systému platného po staletí. A v neposlední řadě podílu místních obyvatel na činnosti teroristických uskupení, pro která se Sinaj, bez kontroly centrální káhirské vlády a při hranici s nenáviděným Izraelem, stala vhodným teritoriem pro prrípravu a samotné provádění teroristických aktů.

Egyptsko-izraelská mírová smlouva byla uzavřena s cílem ukončit válečný stav mezi oběma zeměmi a svým obsahem primárně zohledňovala válku, [18] přestože zahrnuje i ustanovení uplatnitelná na současný stav ve vztahu k terorismu v oblasti.

Demilitarizace poloostrova umožnila více než 30leté období klidu ve vztazích mezi signatáři, nicméně též vytvořila prostor pro ztrátu kontroly centrální egyptské vlády nad bezpečnostní situací na tomto území, a to bez ohledu na skutečnost, že jen špatná vláda, at již svou neschopností nebo svým nezájmem, takový vývoj dopustí. Pravdou je, že ani při vědomí tohoto dramatického stavu na Sinaji nevyužívá egyptská armáda veškerých možností, kterými disponuje k tomu, aby situaci proměnila k lepšímu. Přestože jí nelze upřít provádění patřičně mediálně pokrytých menších operací a vojenských akcí proti jednotlivým skupinám džihádistů, rozhodně se nejedná o komplexní a dlouhodobou disymetrickou [19] vojenskou kampaň s předem stanoveným strategickým cílem. Za této situace nelze nepovažovat za podložené zprávy arabských médií al-Jazeera 
a al-Arabiya o úderu izraelského bezpilotního prostředku na čtyři příslušníky teroristické skupiny Ansar Bajt al-Maqdis v okamžiku, kdy se připravovali odpálit rakety na izraelské území.

Na druhé straně je třeba mít na zřeteli složitou vnitropolitickou a bezpečnostní situaci v centrální části Egypta a není tedy divu, že velení egyptských ozbrojených sil klade důraz na soustředění armádních jednotek v tzv. nilské oblasti a největších metropolích. Tento postoj je navíc akcentován vývojem událostí v prvních červencových dnech 2013, kdy vicepremiér a ministr obrany Mursího vlády generál Abdal Fatáh el-Sísí, podporovaný armádou, zbavil prezidenta Muhammada Mursího vlády, dočasně pozastavil platnost ústavy a výkonem funkce prezidenta dočasně pověřil předsedu ústavního soudu.

Další vývoj v oblasti je nepředvídatelný, ale s jistotou lze tvrdit, že Sinaj je dalším místem na zeměkouli, které se proměnilo způsobem, jenž nedává prostor optimismu pozitivního vývoje v oblasti, která je již tak poznamenána negativními dopady tzv. arabského jara a celkové blízkovýchodní situace trvající již více než 65 let.

\section{Poznámky k textu a bibliografie:}

[1] Egypt Sinai Peninsula [on line]. The current CIA world fact book in Spreadsheet Format [cit. 2013-

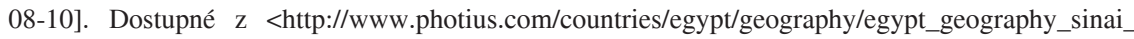
peninsula.html>.

[2] About Sinai [on line]. El Manshia El Gedida [cit. 2013-08-10]. Dostupné z <http:// http://www.bedawi. com/Sinai_EN.html>.

[3] Fedajíni (Fedayeens) - „ti, kdo se obětují“; označení náboženských či politických uskupení, jehož členové jsou ochotni obětovat pro svoji věc život. V našem kontextu označuje skupiny, vytvářející se v palestinských uprchlických táborech po válce za nezávislost v letech 1948-1949. Část z nich se později stala členy OOP, Fatáhu nebo Hamásu. Za fedajíny se někdy označují i jednotliví sebevražední atentátníci a nezávislé skupiny odporu (podle KRUPP, Michael. Dějiny státu Izrael. Vydání první. Praha: Vyšehrad, 2013. 207 s. ISBN 978-80-7429-295-8).

[4] KRUPP, Michael. Dějiny státu Izrael. Vydání první. Praha: Vyšehrad, 2013. 207 s. ISBN 978-807429-295-8.

[5] HERZOG, Chaim. Arabsko-izraelské války. Vydání první. Praha: Nakladatelství Lidové noviny, 2008. 617 s. ISBN 978-80-7106-954-6.

[6] BAKER, Alan. Sinai, the New Egypt, and the Egypt-Israel Peace Treaty [online] Jeruzalém: Jerusalem Center for Public Affairs, 2012 [cit. 2013-08-10]. Dostupné z <http:// jcpa.org/article/sinai-the-newegypt-and-the-egypt-israel-peace-treaty/>.

[7] Peace Treaty between Israel and Egypt [online]. Israel Ministry of Foreign Affairs. Jeruzalém, 1979 [cit. 2013-08-10]. Dostupné z <http://mfa.gov.il/MFA/ForeignPolicy/Peace/Guide/Pages/Israel-Egypt $\% 20$ Peace\%20Treaty.aspx>.

[8] Multinational Force and Observers [online]. Řím: MFO Rome Headquarters, 2013 [cit. 2013-08-11]. Dostupné $\mathrm{z}<\mathrm{http} / / /$ http://mfo.org/>.

[9] Zkušenost autora z pracovních návštěv velitelství MFO a jeho služebního působení v Izraeli v letech 2009 až 2012.

[10] SCHENKER, David. Chaos in the Sinai: Will International Peacekeepers Be the Next Casualty? [online]. Washington, D. C.: The Weekly Standard, 2013 [cit. 2013-08-11]. Dostupné z <http://www. weeklystandard.com/blogs/chaos-sinai-will-international-peacekeepers-be-next-casualty_728974. html>.

[11] KHOURY, Jack - COHEN, Gili - YAGNA, Yanir. Dozens of militants attack peacekeeper headquarters in Sinai, three wounded [online]. Jeruzalém: Haaretz, 2012 [cit. 2013-08-11]. Dostupné z <http:// www.haaretz.com/news/middle-east/dozens-of-militants-attack-peacekeeper-headquarters-in-sinaithree-wounded-1.465096>.

[12] Súfismus - směr islámu, který je založen na uvědomování si viditelného a neviditelného. Slova „fakír“ (arabské) a „darvíšs“ (perské), obě s významem „,chudý“, se používají pro označení súfistů ve vztahu 
k jejich chudému nebo potulnému životu (podle HAERI, Šajch Fadhlalla. Základy islámu. Vydání první. Olomouc: Votobia, 1997. 237 s. ISBN 80-7198-212-1.) Súfismus u muslimů představuje mystiku, kdy název je odvozen od arabského slova súfí znamenající „mystik“ pocházejícího nejspíš ze slova „súf“, označujícího hrubou vlněnou látku, z níž se šil oděv súfíjů, stoupenců tohoto směru, připomínajících někdejší proroky. Súfismus se vyvíjel především v Iráku a Íránu a dal rovněž vzniknout mystickým bratrstvům (podle BOELLE, Cathy - CHEMLA, Chantal - RASTETTER, Nicole. Klíc k náboženství. Vydání první. Praha: Albatros, 2006. 160 s. ISBN 80-00-01679-6).

[13] Saláfisté - militantní skupiny extrémistických sunnitů, kteří se považují za jediné správné interprety Koránu a umírněné muslimy za nevěřící; snaží se přesvědčit všechny ostatní muslimy, že jejich vlastní fundamentální verze islámu ovládne svět (podle The Free Dictionary [cit. 2013-08-12]. Dostupné z < http://www.thefreedictionary.com/Wahhabism>).

[14] Wahabismus (Wahhabism) - muslimská sekta založená Abdulem Wahhábem v 18. století; známá pro př́ísné dodržování Koránu a rozš̌iřená zejména na Arabském poloostrově (podle The Free Dictionary [cit. 2013-08-12]. Dostupné z <http://www.thefreedictionary.com/Salafism>). Wahabismus je některými muslimy považován za saúdskou formu saláfismu (podle BLANCHARD, Christopher. The Islamic Traditions of Wahhabism and Salafiyya. Washington, D. C.: CRS Report for Congress, RS21695, 2008 [cit. 2013-08-12]. Dostupné z < http://www.fas.org/sgp/crs/misc/RS21695.pdf>).

[15] YAARI, Ehud. Sinai. A new front [online]. Washington, D. C.: The Washington Institute for Near East Policy, 2012 [cit. 2013-08-11]. Dostupné z <http://www.washingtoninstitute.org/uploads/Documents/ pubs/PoilicyNote09.pdf>.

[16] NOVOTNÝ, Milan. Bezpečnostní situace na Sinajském poloostrově. Seminární práce. Brno: Masarykova univerzita, Fakulta sociálních studií, Katedra mezinárodních vztahů a evropských studií, 2013, 8 s. Nepublikováno.

[17] BURGROVÁ, Helena. (Ne)bezpečná Sinaj? Mezinárodní politika [online]. Praha: Ústav mezinárodní vztahů, 2013 [cit. 2013-08-11]. Dostupné z <http://www.ustavmezinarodnichvztahu.cz/article/ne-bezpecna-sinaj>.

[18] Válka - forma ozbrojeného konfliktu, v němž jsou nasazeny státní ozbrojené síly (podle EICHLER, Jan. Mezinárodní bezpečnost v době globalizace. Vydání první. Praha: Portál, 2009, 328 s. ISBN 97880-7367-540-0).

[19] Disymetrický konflikt - iniciativa je na straně silněǰ̌ího, který cílevědomě zasazuje zničující údery slabšímu protivníkovi, a snaží se ho co nejrychleji zničit (podle EICHLER, Jan. Operace Serval 2013: Nasazení francouzské armády v Mali. Vojenské rozhledy, 2013, roč. 22, č. 2, s. 133-149, ISSN 12103292).

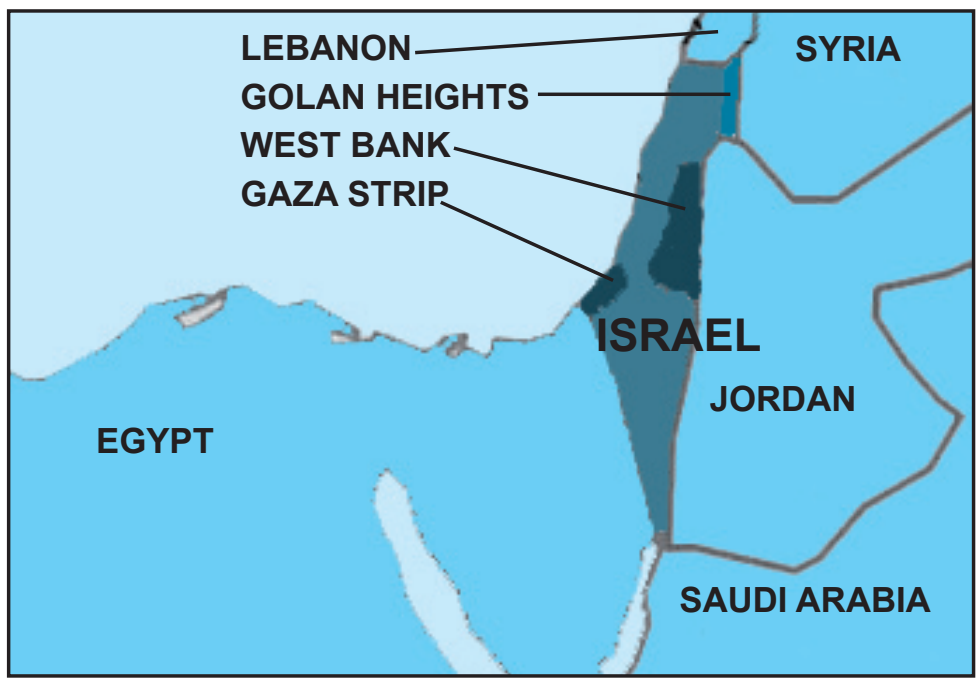

Zdroj: www.mapsofworld.com/israel/ 